\title{
Fundamental Rights-Oriented Repression in the EU? Exploring the Potential and Limits of an Impunity Rationale to Justify Criminalisation in the EU Legal Order
}

\author{
JANNEMIEKE OUWERKERK
}

\section{Introduction}

The quest for the potential and limits of an impunity rationale to justify EU-level criminalisation of conduct brings up the close relationship between human rights and criminal law - a relationship with a rather paradoxical character, though. Whereas human rights traditionally serve to afford protection from the criminal law, the repressive and coercive powers of the criminal law have also been called on, precisely to protect human rights. This has become particularly noticeable in the case law of the dominant human rights actor in Europe: the European Court of Human Rights (ECtHR).

Under the development of the concept of positive obligations, ${ }^{1}$ ECtHR case law has inferred obligations for states to use the criminal law to prevent impunity and, hence, to effectively safeguard the rights of victims of fundamental rights infringements. Probably the most well-known is the Court's judgment in $X$ and $Y v$ the Netherlands. In this case, the father of a mentally ill young girl complained of his inability to institute criminal proceedings against the individual

\footnotetext{
${ }^{1}$ The 1968 Belgian Linguistic case was the first case in which the ECtHR accepted a duty to take action, after which the concept developed further and was gradually interpreted as not only applying in the relationships between states and individuals, but also in the horizontal relationships between individuals, provided that the state can be held responsible for violations of ECHR rights between them. See JF Akandji-Kombe, Positive Obligations under the European Convention on Human Rights. A Guide to the Implementation of the European Convention on Human Rights (Strasbourg, Council of Europe, 2007) 14-15.
} 
who allegedly raped her; under the Dutch law at that time, criminal proceedings could only be instituted upon a complaint lodged by the victim herself. In its judgment, the Court held that this constituted a violation of the right to respect for private life under Article 8 of the European Convention on Human Rights (ECHR):

the protection afforded by the civil law in the case of wrongdoing of the kind inflicted on Miss $\mathrm{Y}$ is insufficient. This is a case where fundamental values and essential aspects of private life are at stake. Effective deterrence is indispensable in this area and it can be achieved only by criminal-law provisions; indeed, it is by such provisions that the matter is normally regulated. ${ }^{2}$

In subsequent judgments, the requirement to take recourse to the criminal law has appeared much more often in ECtHR case law, both in the context of Article $8^{3}$ and under other articles, such as Article 2 (right to life) ${ }^{4}$ and Article 3 (prohibition of torture). ${ }^{5}$ In most of these cases, the actual complaints concerned procedural obstacles in states' law enforcement machineries, such as in the $X$ and $Y$ case. But there have also been cases dealing directly with offence definitions and their interpretations in criminal courts. For instance, in the case of $M C v$ Bulgaria, the applicant complained about the legal interpretation of the definition of rape, according to which physical resistance by the victim had to be proven. ${ }^{6}$ The Court held that such an interpretation violates both Article 3 and Article 8 ECHR as it fell short of the requirements under states' positive obligations 'to establish and apply effectively a criminal-law system punishing all forms of rape and sexual abuse. ${ }^{7}$

As mentioned, in most of the other cases, complaints were primarily dealing with procedural obstacles during criminal investigations and prosecutions. Nevertheless, in many such cases, positive obligations to criminalise conduct have been adopted too. The Court's reasoning in such cases usually relies on the very acceptance of positive obligations to enact criminal prohibitions in the area of crime concerned - which, in turn, requires that such prohibitions can be

\footnotetext{
${ }^{2} X$ and $Y v$ the Netherlands App no 8978/80 (ECtHR, 26 March 1985) para 27.

${ }^{3}$ See, eg MC v Bulgaria App no 39272/98 (ECtHR, 4 December 2003); See also KU v Finland App no 2872/02 (ECtHR, 2 December 2008).

${ }^{4}$ See, eg Osman v United Kingdom App no 23452/94 (ECtHR, 28 October 1998), confirmed several times, eg in Mastrometto $v$ Italy App no 37703/97 (ECtHR, 24 October 2002); Nikolova \& Velichkova $v$ Bulgaria App no 7888/03 (ECtHR, 20 December 2007); Cesnulevicius v Lithuania App no 13462/06 (ECtHR, 10 January 2012).

${ }^{5}$ Most well known is MC $v$ Bulgaria (n 3), which gave rise to an issue under both Art 8 ECHR and Art 3 ECHR. The Court's ruling in this case has been confirmed a number of times, eg in DJ $v$ Croatia App no 42418/10 (ECtHR, 24 July 2012).

${ }^{6}$ Under Bulgarian criminal law, rape was defined by reference to the means used by the perpetrator, ie 'force' or 'threats', and there were indications in Bulgarian case law that for those means to be proven, evidence of physical resistance was mostly required: see $M C v$ Bulgaria (n 3) paras 169ff.

${ }^{7}$ MC v Bulgaria (n 3) para 185 (emphasis added).
} 
effectively applied in practice, meaning that procedural rules resulting in leaving crime unpunished can be held to violate ECHR rights. ${ }^{8}$

In doing so, the ECtHR has acknowledged that the criminal law is not only a potential 'threat', but can also be a 'protection' for fundamental rights. ${ }^{9}$ In other words, in the application of criminal law, human rights can function both as a 'shield' and as a 'sword.' 10

The shield function of fundamental rights in the application of the criminal law reflects very well its primary and traditional role of affording protection from the indiscriminate and excessive use of the criminal law. Therefore, it has never really been called into question. However, it is quite another story where fundamental rights function as a sword, triggering the application of criminal law. From a historical perspective, this is hardly surprising. Besides, in response to the ECtHR's use of the criminal law option, it has been pointed out that this has constituted a potentially problematic paradigm shift. This is because it remains unclear whether and how the ECtHR takes sufficient account, in its judgments, of relevant interests other than fundamental rights interests alone, such as the desirability and effectiveness of the criminal law option, or the existence of adequate alternatives to criminal law responses. ${ }^{11}$

Can similar or otherwise critical observations also be made with regard to the functioning of fundamental rights in the application of EU criminal law? Initially primarily an organisation for trade and economic cooperation, the present-day European Union is, moreover, considered a fundamental rights actor too. Lately, the EU has been quite active in the criminal law domain. This raises the question how fundamental rights actually function in the context of EU criminal law, and

\footnotetext{
${ }^{8}$ See again $X$ and $Y v$ the Netherlands (n 2) and accompanying text. See also KU v Finland (n 3), regarding the inability of Finnish law enforcement officials to oblige a service provider to reveal the identity of a person who on its website had placed a defamatory dating advertisement in the name of a 12-year-old boy. According to the Court, this procedural obstacle constituted a violation of the applicant's rights under Art 8 ECHR since the inability to identify the offender compromises effective criminal investigations and prosecutions in cases such as the underlying case, paras 46, 49-50.

${ }^{9}$ The terms 'threat' and 'protection' are borrowed from M. Delmas-Marty's chapter on 'Le paradoxe pénal' in: M. Delmas-Marty \& C. Lucas de Leyssac (eds), Libertés et droits fondamentaux, Paris: Seuil 1996, p. 368, where she states: 'le droit pénal semble tout à la fois protection et menace pour les libertés et droits fondamentaux'.

${ }^{10}$ A 2007 edited volume has been dedicated to this paradox: Y Cartuyvels et al (eds), Les droits de l'homme, bouclier ou épée du droit penal? (Brussels, Presses de l'Université Saint-Louis, 2007). See also F Tulkens, 'The Paradoxical Relationship between Criminal Law and Human Rights' (2011) 9 Journal of International Criminal Justice 578, fn 5 and accompanying text.

${ }^{11}$ PHPHMC van Kempen, Repressie door mensenrechten. Over positieve verplichtingen tot aanwending van strafrecht ter bescherming van mensenrechten (Utrecht, Wolf Legal Publishers, 2008) 66, 80; JW Ouwerkerk, 'Criminalisation as a Last Resort: A National Principle under the Pressure of Europeanisation?' (2012) 3 New Journal of European Criminal Law 239-240. See also para 2 of Tulkens's concurring opinion to the ECtHR judgment in MC v Bulgaria (n 3), in which she underlines that 'it is also important to emphasise on a more general level, as, indeed, the Court did in $X$ and $Y v$ the Netherlands itself, that "[r] ecourse to the criminal law is not necessarily the only answer".
} 
in particular whether and how impunity may constitute a relevant factor in the exercise of criminalisation powers.

This chapter provides an attempt to answer these questions and offers food for further reflection on the matter. To that end, it starts with a brief account of how the close relationship between fundamental rights and criminal law has come into play in the EU legal order, and to what extent this relationship has become affected by the 'shield and sword' paradox (section II). Subsequently, it explores the limits and potential of applying a fundamental rights-oriented impunity rationale to the adoption of criminalisation duties in the EU legal order. To that end, it discusses, first, the incompleteness of such an approach (section III); and, secondly, how such an impunity rationale could and should function in the exercise of EU criminalisation powers (section IV), both from an institutional lawmaking perspective (section IV.A) and from a substantive perspective (section IV.B). This chapter closes with some final remarks.

\section{EU Criminal Law and the Emergence of Fundamental Rights in the EU Legal Order}

Since the entry into force of the Treaty of Lisbon, the protection and further advancement of fundamental rights have obtained a prominent place in the institutional legal framework of the EU. The EU Charter of Fundamental Rights (the Charter) is now a legally binding instrument (Article 6(1) TEU) and the EU is legally obliged to accede to the ECHR (Article 6(2) TEU). Moreover, respect for human rights has been recognised as a foundational value of the EU (Article 2 TEU). ${ }^{12}$ This development has been welcomed by many, not least by criminal law experts. ${ }^{13}$ Especially since the introduction and implementation of the mutual recognition principle, there has been a widely shared concern that EU action in the criminal law domain has been too one-sided, focusing on cross-border law enforcement and repression without proper attention for due process rights. ${ }^{14}$ The increased attention for fundamental rights protection under the Lisbon

\footnotetext{
${ }^{12}$ For further on this development, see G de Búrca, 'The Road Not Taken: The EU as a Global Human Rights Actor' (2011) 105 The American Journal of International Law 649.

${ }^{13}$ See, eg both inside and outside the criminal law domain: E Herlin-Karnell, The Constitutional Dimension of European Criminal Law (Oxford, Hart Publishing, 2012) 231-32; F van den Berghe, 'The EU and Issues of Human Rights Protection: Some Solutions to More Acute Problems' (2010) 16 European Law Journal 112; S Douglas-Scott, 'A Tale of Two Courts: Luxembourg, Strasbourg and the Growing European Human Rights Acquis' (2006) 46 CML Rev 629.

${ }^{14}$ In the specific context of the European Arrest Warrant mechanisms, concerns and reliefs have been described well by L Mancano, 'A New Hope? The Court of Justice Restores the Balance between Fundamental Rights Protection and Enforcement Demands in the European Arrest Warrant System' in C Brière and A Weyembergh (eds), The Needed Balances in EU Criminal Law. Past, Present and Future (Oxford, Hart Publishing, 2017).
} 
regime has therefore been argued to have constituted a paradigm shift in the EU criminal justice area:

the construction of Europe's area of criminal justice has moved from a paradigm privileging the interests of the state and of law enforcement under a system of quasi-automatic mutual recognition to a paradigm where the rights of individuals affected by such system are brought to the fore, protected and enforced in EU law. ${ }^{15}$

The many complaints that no sufficient attention was paid to due process rights in criminal proceedings prior to Lisbon suggests that a stronger engagement of the EU with fundamental rights was generally expected to particularly boost and strengthen the shield function of fundamental rights in the application of EU-governed criminal law measures - expectations that at least partly may have been fulfilled through the gradual adoption of Directives on procedural rights for suspects in criminal proceedings. Between 2010 and 2016, a respectable number of common minimum norms has been adopted, covering the rights to interpretation and translation, the right to information, the right of access to a lawyer, the right to communicate with third persons and consular authorities, the presumption of innocence, the right to be present at trial, the right to state-paid legal aid, and rights specific to children who are suspected of crime. ${ }^{16}$

In addition to this obvious protective approach, it must at the same time be observed that the EU Court of Justice (CJEU) has recognised the prevention of impunity as a relevant interest in assessing the scope of fundamental rights protection in the context of criminal proceedings. In the Spasic case, dealing with the scope of the ne bis in idem principle, the CJEU was asked whether the so-called enforcement condition laid down in Article 54 of the Convention Implementing the Schengen Agreement $(\mathrm{CISA})^{17}$ is compatible with Article 50 of the Charter, in which Union-wide protection against double prosecutions and

\footnotetext{
${ }^{15} \mathrm{~V}$ Mitsilegas, EU Criminal Law after Lisbon. Rights, Trust and the Transformation of Justice in Europe (Oxford, Hart Publishing, 2016) 183.

${ }^{16}$ Directive 2010/64 on the right to interpretation and translation in criminal proceedings [2010] OJ L280/01; Directive 2012/13 on the right to information in criminal proceedings [2012] OJ L142/1; Directive 2013/48 on the right of access to a lawyer in criminal proceedings and in European arrest warrant proceedings, and on the right to have a third party informed upon deprivation of liberty and to communicate with third persons and with consular authorities while deprived of liberty [2013] OJ L294/1; Directive 2016/343 on the strengthening of certain aspects of the presumption of innocence and of the right to be present at the trial in criminal proceedings [2016] OJ L65/1; Directive $2016 / 800$ on procedural safeguards for children who are suspects or accused persons in criminal proceedings [2016] OJ L132/1; Directive 2016/1919 on legal aid for suspects and accused persons in criminal proceedings and for requested persons in European arrest warrant proceedings [2016] OJ L297/1.

${ }^{17}$ Art 54 CISA reads as follows: 'A person whose trial has been finally disposed of in one Contracting Party may not be prosecuted in another Contracting Party for the same acts provided that, if a penalty has been imposed, it has been enforced, is actually in the process of being enforced or can no longer be enforced under the laws of the sentencing Contracting Party.' The CISA has been integrated into EU law; the currently applicable protocol is Protocol 19 to the Treaty of Lisbon [2012] OJ C326/1.
} 
double punishments would apply irrespective of whether the sanction has been imposed. ${ }^{18}$ The CJEU ruled in the affirmative, ${ }^{19}$ arguing that the ne bis in idem principle, enshrined in Article 54 CISA, has a twofold aim, ie to prevent impunity and to ensure legal certainty:

The ne bis in idem principle set out in Article 54 CISA is intended not only to prevent, in the area of freedom, security and justice, the impunity of persons definitively convicted and sentenced in the European Union but also to ensure legal certainty through respect for decisions of public bodies which have become final, in the absence of harmonisation or approximation of the criminal laws of the Member States. ${ }^{20}$

Under the principle's aim to avoid impunity, it was also held that the application of the enforcement condition does constitute a limitation of the ne bis in idem principle, albeit a proportionate limitation in view of the very aim to avoid impunity: 'It follows that the execution condition laid down in Article 54 CISA does not go beyond what is necessary to prevent, in a cross-border context, the impunity of persons definitively convicted and sentenced in the European Union.21

The arguments that have been put forward by the CJEU in the Spasic case demonstrate that the scope of protection of fundamental rights in the EU legal order is not necessarily defined by protective rationales; in Spasic, the CJEU explicitly relied on an impunity rationale. ${ }^{22}$ The Spasic judgment therefore illustrates how an impunity rationale can trigger the limitation of fundamental rights protection in EU law and, hence, can give rise to the application of law enforcement activities which could not have been applied under a protective rationale-based interpretation of Article 50 of the Charter. Therefore, although the Spasic case concerns a case of cross-border judicial cooperation, the judgment demonstrates well how the relationship in EU law between fundamental rights and criminal law has become affected by the 'shield and sword' paradox.

The increased engagement of the EU with fundamental rights makes it plausible to expect more occasions to come in which fundamental rights may be invoked to justify the use of criminal law measures. One of these occasions regards the further development of an EU criminalisation policy. Fundamental rights interests, in more general terms, have indeed been invoked in this context, in particular in the exercise of criminalisation competences under Article 83(1) TFEU (regarding the so-called Euro-crimes). For instance, preambles to the latest Directives in the areas of child sexual abuse and terrorism state that these Directives concern offences that constitute serious violations of fundamental rights. ${ }^{23}$

\footnotetext{
${ }^{18}$ Art 50 of the Charter states: 'No one shall be liable to be tried or punished again in criminal proceedings for an offence for which he or she has already been finally acquitted or convicted within the Union in accordance with the law.'

${ }^{19}$ Case C-129/14 Spasic ECLI:EU:C:2014:586, para 74.

20 ibid para 77.

${ }^{21}$ ibid para 72 .

${ }^{22}$ Indicated as a 'security rationale' in Mitsilegas (n 15) 90.

${ }^{23}$ Recital 1 of the Preamble to Directive 2011/93 on combating the sexual abuse and sexual exploitation of children and child pornography [2011] OJ L335/1 reads as follows: 'Sexual abuse and
} 
Impunity arguments have been invoked too in the context of criminalisation legislation, though always rather implicitly. On several occasions, the European Commission has accompanied its criminalisation proposals with the argument that differences in scopes of national criminal prohibitions hinder the optimal application of judicial cross-border cooperation mechanisms. For instance, in the context of child sexual abuse, it was held that shared definitions of offences in this field would prevent criminals from choosing national jurisdictions with more lenient criminal laws to commit their crimes, but also that shared norms would facilitate cross-border cooperation, hence the fight against such crimes. ${ }^{24}$ Such reasoning amounts to a security or impunity argument, for it suggests that a reduction of disparities in substantive criminal law may lower the chances that perpetrators go unpunished.

Now the question arises how convincing such an impunity argument is, and can be - and, hence, whether impunity concerns justify the development of a fundamental rights-oriented criminalisation policy in the EU legal order. The following sections will share some exploratory reflections on these questions, in an attempt to contribute to the scholarly debate on the matter.

\section{The Reductionist Nature of a Fundamental Rights-Oriented Approach}

In discussing whether criminalisation processes should be governed by fundamental rights-based arguments, a first significant question that arises is to what extent such fundamental rights-based arguments can be decisive in justifying

sexual exploitation of children, including child pornography, constitute serious violations of fundamental rights, in particular of the rights of children to the protection and care necessary for their well-being, as provided for by the 1989 United Nations Convention on the Rights of the Child and by the Charter of Fundamental Rights of the European Union'; and in Recital 2 of the Preamble to Directive 2017/541 on combating terrorism [2017] OJ L88/6 it is stated that Acts of terrorism constitute one of the most serious violations of the universal values of human dignity, freedom, equality and solidarity, and enjoyment of human rights and fundamental freedoms on which the Union is founded'.

${ }^{24}$ European Commission, Proposal for a Directive of the European Parliament and of the Council on combating the sexual abuse and sexual exploitation of children and child pornography, and replacing Council Framework Decision 2004/68/JHA, COM (2010) 94 final (the proposal was originally submitted as a draft Framework Decision, COM (2009) 135 final, but following the entry into force of the Lisbon Treaty, the proposal was amended into a draft Directive), Explanatory Memorandum, 2, para 1; Commission Staff Working Document, Impact Assessment, Accompanying document to the Proposal for a Directive of the European Parliament and of the Council on combating the sexual abuse and sexual exploitation of children and child pornography, and replacing Council Framework Decision 2004/68/JHA, SEC (2009) 355 final, paras 2.2, 2.4, 3.1 and 4.3. For more examples of such reasoning in Commission's proposals, see J Ouwerkerk, 'The Potential of Mutual Recognition as a Limit to the Exercise of EU Criminalisation Powers' (2017) 7 European Criminal Law Review 9, followed by a critical appraisal from the perspective of mutual recognition. 


\section{Jannemieke Ouwerkerk}

criminalisation of conduct. In addressing this question, I would like to point out the inherently reductionist ${ }^{25}$ nature of a rights-oriented approach.

As convincingly demonstrated by legal scholarship in the field of criminal procedure theory, it is problematic to frame doctrines in this area predominantly in terms of individual rights. That is not only because the contours of such a rationale are unclear (what exactly does the term 'rights' encompass?), but also and perhaps more importantly - because such a framing would wrongfully suggest that in responding to procedural violations committed in the course of criminal proceedings there is only one relevant question, ie the question whether a procedural violation constitutes a violation of an individual fundamental right. ${ }^{26}$ Put differently, approaching matters of procedural violations solely from the perspective of rights ignores the (potential) relevance of other perspectives. Consequently, it also ignores the complexity of criminal procedural standards and their underlying values, which requires the consideration of other perspectives too when determining how to address violations of such procedural standards. Pitcher has shown what the consequences would be when a mere rights rationale (which she refers to as 'the protective rationale') would be applied to the problem of unlawfully obtained evidence in the pretrial stage of criminal proceedings:

the rationale for excluding unlawfully obtained evidence lies in the need to protect... rights of the suspect and accused (ie the rights underlying declared standards for the conduct of criminal investigations) ... Under the protective rationale, then, once it has been established that the evidence in question was obtained by a rights violation (specifically, by violation of the accused's rights), that evidence should, in principle, be excluded. Accordingly, under the protective rationale exclusion is the primary response to pretrial impropriety, and the sole predicate event to the exclusion of evidence is the fact that the evidence in question was obtained in violation of accused's rights (by the public authorities charged with investigating and prosecuting crime). ${ }^{27}$

Consequently, as Pitcher subsequently points out, other factors are not taken into account, not even those factors that are considered highly relevant under the rationales that have been shaping rules on pretrial investigations:

For example, while a relevant consideration under the deterrence rationale, whether the law enforcement officer acted deliberately in obtaining the evidence by improper means is not a relevant consideration under the protective rationale ... Different rationales for responding to pretrial impropriety require (or allow) different factors to be taken into account, so that when certain factors are excluded from consideration ... this may lead to certain rationales and the values underpinning them being overlooked. ${ }^{28}$

\footnotetext{
${ }^{25}$ The term 'reductionist' is borrowed from KM Pitcher, 'Rights-Analysis in Addressing Pre-trial Impropriety: An Obstacle to Fairness?' in J Jackson and S Summers (eds), Obstacles to Fairness in Criminal Proceedings. Individual Rights and Institutional Forms (Oxford, Hart Publishing, 2018) 273.

${ }^{26}$ See, eg P Roberts, 'Excluding Evidence as Protecting Constitutional or Human Rights?' in L Zedner and JV Roberts (eds), Principles and Values in Criminal Law and Criminal Justice: Essays in Honour of Andrew Ashworth (Oxford, Oxford University Press, 2012) 183; Pitcher (n 25).

${ }^{27}$ Pitcher (n 25) 277 (original emphasis).

${ }^{28}$ ibid 278. See also Roberts (n 26) 183.
} 
The individual rights-oriented rationale thus has a reductionist character in the context of criminal procedural law, for it is not well suited to capturing all relevant rationales and underlying values that are at stake, and bears the risk of wrongfully overlooking them. For instance, imagine that, in an individual case, law enforcement authorities commit a number of procedural violations in the course of gathering evidence. But imagine also that the suspect in this case may overall - not have been prevented from receiving a fair trial (eg in the sense of Article $6 \mathrm{ECHR}$ ); from a fundamental rights point of view, no response is required. However, the procedural violations might still be considered to constitute severe violations of the integrity of the criminal proceedings. Such a serious conclusion may well trigger a response, though perhaps a different one than warranted under a fundamental rights-oriented approach (ie exclusion of evidence). ${ }^{29}$

The reductionist nature inherent in the individual fundamental rightsoriented approach to procedural violations also has implications for the position of such an approach in the context of legislating on matters of substantive criminal law. To commence, I would like to recollect the 'shield and sword' paradox this chapter started with: fundamental rights protection may offer a reason to extend the scope of certain criminal prohibitions, but fundamental rights protection may also demand that they be limited, or even abolished. This underscores that even where fundamental rights protection would be the single perspective from which criminalisation issues would be approached, the impunity argument can never be decisive. That would one-sidedly reflect the sword function of the criminal law, whereas fundamental rights instruments traditionally also include rights that particularly express the shield function that fundamental rights also aim to fulfil in the context of criminal law (eg the principles of legality and proportionality).

Besides, in determining the reach of substantive criminal law, there are a number of other factors that are traditionally taken into account for very justifiable reasons. These include factors that cannot be classified as rights of individuals, but nonetheless must be considered likewise significant, for they play an indispensable part in the development of a reasonable and balanced body of substantive criminal law - a multipurpose body of law after all, pursuing, indeed, the protection of fundamental rights, but also the protection of many other values, norms and societal customs. It does this by means of regulating what conduct is acceptable and what is not, and under what conditions individuals can be held liable or, rather, excused. Considering the aim of this chapter, I confine myself to mentioning only a few of these other non-fundamental rightsrelated factors. Most obvious are factors of principle, such as the existence of other possible answers to address the unwanted behaviour (expressing the ultima

\footnotetext{
${ }^{29}$ Pitcher (n 25) 292ff. For more elaboration on this (though available in Dutch only), see KM Pitcher and M Samadi, 'Integriteit als perspectief bij de rechterlijke reactie op vormverzuimen (2018) 59 Delikt en Delinkwent 731.
} 
ratio principle $\mathrm{e}^{30}$ ) or the magnitude of the problem. Other relevant factors are of a more pragmatic nature, such as the actual prosecutability of conduct (including predictable evidentiary problems) and the capacity of the available law enforcement machinery. Their relevance has long since been recognised in the context of national criminal law, and they are increasingly copied at the level of EU criminal law. ${ }^{31}$ They concern factors that acknowledge both the complexity and the multipurpose nature of substantive criminal law, and the variety of rationales that underpin it.

To conclude, due to their reductionist character, the criminalisation policy of the EU cannot be solely based on fundamental rights, nor can impunity arguments be decisive. Such would carry the unforgiveable risk of overlooking other relevant factors and their underlying values. The fundamental rights perspective must be taken into account, all the more since the EU has increasingly been engaging with fundamental rights, ${ }^{32}$ though without losing sight of, first, the shield function that fundamental rights must fulfil in shaping the criminal law, and, secondly, the complexity and multipurpose nature of the criminal law. In the following section, I reflect on how such a task fits into the applicable lawmaking process of the EU, and how the legislator could further advance its efforts in this regard.

\section{The Functioning of Fundamental Rights-Based Impunity Rationales in EU Legislative Practice Concerning Matters of Substantive Criminal Law}

The following will show that the EU lawmaking process applicable to criminalisation acts is, in principle, well suited to using the various relevant rationales to determine the scopes of EU-level criminal prohibitions (section IV.A). Subsequently, however, it will be argued that the pursuit of developing a reasonable and balanced EU-level body of substantive criminal law would benefit from more explicit attention in the legislative procedure to particular offence definitions, instead of maintaining the perspective of the crime areas these definitions fall into (section IV.B).

\footnotetext{
${ }^{30}$ Compare $\mathrm{n} 11$ and accompanying text.

${ }^{31}$ See, eg European Parliament Resolution of 22 May 2012 on an EU approach to criminal law, P7_TA(2012)0208, under point I; European Commission Communication, 'Towards an EU Criminal Policy: Ensuring the effective implementation of EU policies through criminal law', COM (2011) 573 final, para 2.2.1. See also P Asp et al, 'A Manifesto on European Criminal Policy (European Criminal Policy Initiative)' (2009) 4 Zeitschrift für Internationale Strafrechtsdogmatik 707.

${ }^{32}$ As demonstrated in section II.
} 


\section{A. Institutional Perspective}

This section comprises two intertwining parts. First, it demonstrates that the institutional positioning of criminal law competences in the EU legal order facilitates the taking into account of a variety of relevant rationales when EU action is being considered. Based on that, the second claim is that the EU lawmaking process further encourages the legislature to incorporate such different, sometimes competing, rationales and balance them against each other.

As demonstrated in the introduction of this chapter, the use of fundamental rights-based arguments to extend the scope of national criminal prohibitions has been developed in the context of human rights law, predominantly under the Strasbourg doctrine of positive obligations. It has also been mentioned that this development in ECtHR case law has been criticised, in particular out of concern that the Strasbourg Court would fail to take sufficient account of other factors that are considered relevant in determining the scope of substantive criminal law. In its case law on positive duties to criminalise conduct, the Court does occasionally refer to other factors, though this does not seem to be a consistent practice. ${ }^{33}$ Clearly, the question is whether, and to what extent, the Court actually ought to consider these other perspectives, for its duty is to 'ensure the observance of the engagements undertaken by the High Contracting Parties in the Convention and the Protocols thereto' (Article 19 ECHR). Would a similar concern be justified in the context of EU criminal law? Not necessarily.

Within the EU legal order, the conferred powers to enact legislation regarding matters of substantive criminal law are part of a bigger whole - a whole of competences that covers both procedural and substantive criminal law, as well as police and judicial cooperation and the setting up of law enforcement agencies (laid down in Chapters IV and V of Title V TFEU). Yet, from a wider perspective, criminal law competences fall under the broader policy field called the 'area of freedom, security and justice' (AFSJ), which also covers civil law, asylum law and migration law (Title V TFEU). And even beyond the AFSJ, criminal law powers cohere with other powers and principles, such as the power to maintain a borderless area and to safeguard the free movement of persons therein. ${ }^{34}$ In exercising its competences in the field of criminal law, the EU must adhere to the EU Charter on Fundamental Rights (Article 6 TEU), as well as to the governing principles of subsidiarity and proportionality (Article 5 TEU). Consequently, longer term AFSJ and criminal law policies usually concern the areas as a whole, rather than being

\footnotetext{
${ }^{33}$ See, eg KUv Finland (n 3 ) para 48, where it states that 'in view of the difficulties in policing modern societies, a positive obligation must be interpreted in a way which does not impose an impossible or disproportionate burden on the authorities, or, as in this case, the legislator. Another relevant consideration is the need to ensure that powers to control, prevent and investigate crime are exercised in a manner which fully respects the due process and other guarantees which legitimately place restraints on criminal investigations and bringing offenders to justice.'

${ }^{34} \mathrm{cf}$ Mitsilegas (n 15) 125; J Ouwerkerk, Herijking van Uniestrafrecht. Over grondslagen voor strafrechtelijke regelgeving in de Europese Unie (The Hague, Boom juridisch, 2017).
} 
focused on one specific competence in a certain area. ${ }^{35}$ Consequently, lawmaking on specific matters, such as criminalisation, is unlikely to be taken in isolation or by applying a single perspective, such as the perspective of impunity. The institutional positioning of criminal law within the EU legal order stipulates rather that several other factors are taking into account when designing new laws.

Such is being further facilitated through the existence of a well-prescribed and rather detailed legislative process, applicable to criminal law affairs. Usually, upon a Commission's proposal, generally accompanied by an impact assessment, the close involvement of national governments' perspectives (via the European Council) and the European Parliament in such legislative processes secures the possibility of careful weighing up all (perhaps competing) interests involved in the assessment of whether specific behaviours justify the adoption of criminal prohibitions at the EU level. Although there is still much room to critique the way in which this is being done in practice, research shows that usually a variety of factors are invoked and debated. ${ }^{36}$ It justifies the intermediate conclusion that the $\mathrm{EU}$ is, in principle, well suited to involving fundamental rights considerations in its criminalisation policy without losing sight of other factors and their underlying rationales. Be that as it may, the following subsection will explain why the existing practice of lawmaking in the field of criminal law nevertheless deserves to be criticised for how it employs the rights argument and the underlying impunity rationale.

\section{B. The Precise Subject of an Impunity Rationale: Areas of Crime versus Particular Definitions of Offences}

To invoke fundamental rights in order to justify the adoption of criminalisation duties can be rather appealing for the Member States, and are perhaps easily convincing - in particular, when one considers the areas of crime in which the EU is competent to act: terrorism, human trafficking, sexual exploitation of women and children, etc (Article 83(1) TFEU). It goes without saying that these acts constitute gross violations of fundamental rights. Who would not want to prevent impunity for those committing them? But here it is important to observe that recent EU legislative measures regarding criminalisation in these areas of crime

\footnotetext{
${ }^{35}$ See, eg the so-called 'Stockholm programme', adopted in 2009, establishing a five-year policy programme for Justice and Home Affairs, entitled 'An Open and Secure Europe Serving and Protecting the Citizens', Council doc 17024/09 (Brussels, 2 December 2009).

${ }^{36}$ See some overviews (for different purposes) in J Ouwerkerk, 'Evidence-Based Criminalisation in EU Law: Evidence of What Exactly?' in J Ouwerkerk J Atltena, J Öberg and S Miettinen (eds), The Future of EU Criminal Justice Policy and Practice. Legal and Criminological Perspectives (Leiden, Brill/Nijhoff, 2019) 50-56; Ouwerkerk (n 24) 9-15. See also analyses on specific types of crime, eg V Mitsilegas, 'The Normative Foundations of the Criminalization of Human Smuggling: Exploring the Fault Lines between European and International Law' (2019) 10 New Journal of European Criminal Law 77; J Öberg, 'Is It 'Essential' to Imprison Insider Dealers to Enforce Insider Dealing Laws?' (2014) 14 Journal of Corporate Law Studies 111.
} 
do not concern the core crimes. After all, the latest Directives regarding these areas of crime did not define for the first time what according to EU law is to count as terrorism, human trafficking or sexual exploitation; these were already defined in previous legislation which has now been replaced by new, more extensive provisions (adopted under the umbrella of the Lisbon Treaty). ${ }^{37}$ These latest Directives rather deal with so-called 'related offences'. The question really is how convincing fundamental rights-based justifications and impunity arguments are in relation to those related offences.

Before turning to this question, it is instructive to illustrate how the rights argument has been used in the latest EU Directive on Terrorism. Directive 2017/541 aims to replace its 2002 predecessor, merely by extending the scopes of prohibited conduct related to terrorism. ${ }^{38}$ To that end, Directive 2017/514 covers an impressive number of newly incriminated types of conduct, called 'offences related to terrorist activities'. It concerns: public provocation to commit a terrorist offence, recruitment for terrorism, providing training for terrorism, receiving training for terrorism, travelling for the purpose of terrorism, organising or otherwise facilitating travelling for the purpose of terrorism, and terrorist financing. ${ }^{39}$ In the explanatory notes to its proposal for this Directive, the Commission explicitly mentioned the serious violations of fundamental rights that 'acts of terrorism' constitute, for which reason it considers EU action in the field justified. ${ }^{40}$ In an account of evaluations of then existing legislation as well as impact assessments, the Commission further elaborated on the relationship between fundamental rights protection and the need for stronger terrorism legislation. It explicitly mentions that the proposed measures 'have as final objective the protection of fundamental rights of victims and potential victims, in particular the right to life and the right to physical and mental integrity. ${ }^{41}$ But whether and to what extent the protection of fundamental rights also requires the incrimination of all aforementioned terrorism-related offences, or whether that specific argument only applies to the core terrorist offences, has not been explained. Only in rather general terms has it been stated that criminal prohibitions must in any case 'comply with the principles of necessity, proportionality, and legality, with appropriate safeguards to ensure accountability and judicial redress. ${ }^{4}$

These general wordings and references related to fundamental rights protection strongly suggest that the fundamental rights argument has merely been

\footnotetext{
${ }^{37}$ Directive 2017/541 on combating terrorism [2017] OJ L88/6; Directive 2011/36 on preventing and combating trafficking in human beings and protecting its victims, replacing Council Framework Decision 2002/629/JHA [2011] OJ 2011 L101/1; Directive 2011/93 on combating sexual abuse (n 23).

${ }^{38}$ Council Framework Decision 2002/475/JHA on combating terrorism [2002] OJ L164/3.

${ }^{39}$ Directive 2017/541 (n 37) Art. 5-11.

${ }^{40}$ European Commission, Proposal for a Directive of the European Parliament and of the Council on combating terrorism and replacing Council Framework Decision 2002/475/JHA on combating terrorism, COM (2015) 625 final, 1, para 1.

41 ibid 13 , para 3.

${ }^{42}$ ibid 13-14, para 3.
} 
used to justify legislative action at the level of the crime area concerned (here, terrorism), instead of justifying legislative action at the level of particular offence definitions within this specific crime area. This corresponds to what has happened regarding other areas of crime, such as human trafficking and sexual exploitation. Whereas the latest (and in the meantime adopted) Commission's proposals for new Directives in these areas also aim to define criminal prohibitions concerning 'related offences' only, accompanying justifications have predominantly been put forward relating to the respective areas of crime, without mentioning consistently specific proposals regarding 'related offences. ${ }^{43}$

The practice described above may be problematic, because it wrongfully suggests that justifications at the level of a crime area automatically equate with justifications at the level of specific incriminations. After all, one argument may well justify incrimination of the core offence (terrorist attack), but will not necessarily justify either incrimination of a related act (eg terrorist financing) $)^{44}$ or incrimination of acts in a pre-emptive or anticipative stage (eg attempts and preparatory acts). Therefore, in order to further advance a legitimate criminalisation policy, and a fair position of rights-oriented impunity arguments therein, it is necessary to use such arguments in a much more specific manner than has been done so far. Instead of linking them to the applicable crime area as a whole, they should be made in relation to particular criminal prohibitions.

\section{Final Remarks}

It has been demonstrated in this chapter that the EU's increased engagement with fundamental rights has triggered both their shield and their sword function in the context of criminal law. Fundamental rights have, on the one hand, been invoked to protect citizens from the application of the criminal law, but, on the other hand, have also been invoked to trigger the very application of the criminal law, for instance by compelling Member States to enact certain criminal prohibitions in their national legal orders. The latter use of fundamental rightsbased arguments shows an increased attention for the impunity rationale in EU substantive criminal law.

\footnotetext{
${ }^{43}$ Regarding human trafficking, see Recitals 1 and 11 to Directive 2011/36 on preventing and combating trafficking in human beings and protecting its victims [2011] OJ L101/1; Commission Staff Working Document, Impact Assessment, Accompanying document to the Proposal for a Council Framework Decision on preventing and combating trafficking in human beings, and protecting victims, SEC (2009) 359, in particular paras 2.7 and 5.3.3. Regarding sexual offences, see the Explanatory Memorandum to the European Commission's Proposal for a Directive (n 24) 2, para 1 and 8, para 3; see also the accompanying Impact Assessment (n 24), in particular paras 2.2 and 2.8.

${ }^{44}$ Especially if one considers the very broad scope of the applicable provision: Art 11 of Directive $2017 / 541$ (no 37) requires the prohibition of 'providing or collecting funds, by any means, directly or indirectly, with the intention that they be used, or in the knowledge that they are to be used, in full or in part, to commit, or to contribute to the commission of, any of the offences referred to in Articles 3 to 10 '.
} 
In a subsequent exploration of the potential and limits of such an impunity rationale in the context of EU criminalisation policy, it has been argued that the utmost limit of a right to impunity follows from the inherent reductionist nature of rights-based arguments. Would such arguments be made decisive, there is a real risk that other factors of relevance to the criminalisation process would wrongfully be overlooked. Against that background, it has been shown that decision-making processes in the context of EU criminal law and policy are quite well suited to focusing on all interests at stake in determining the scope of substantive criminal law at the EU level. However, to further advance legitimate law, and policy-making in EU criminal law, it has been recommended that justifications for EU-level incrimination must be given, to an increasing extent, at the level of specific offence definitions, rather than at the level of crime areas only. Here also lies a task for legal scholarship on EU criminal law which, contrary to national-oriented scholarship on substantive criminal law, predominantly discusses competences and the exercise thereof in relation to areas of crime, but should feel encouraged to increasingly engage with discussing specific definitions of offences, including those that qualify as related offences or pre-emptive or anticipative acts of crime. 
